Karyn Lai, Rick Benitez and Hyun Jin Kim (eds.) Cultivating a Good Life in Early Chinese and Ancient Greek Philosophy: Perspectives and Reverberations, 2018, London: Bloomsbury Press, pp. 193-207

\author{
This is the pre-print version. The definitive version is available at https:// \\ www.bloomsbury.com/us/cultivating-a-good-life-in-early-chinese-and- \\ ancient-greek-philosophy-9781350049574/
}

\title{
Learning to Be Reliable: Confucius' Analects
}

\author{
Karyn Lynne Lai
}

\begin{abstract}
Reciting the Odes can arouse your sensibilities, strengthen your powers of observation, enhance your ability to get on with others, and sharpen your critical skills. Close at hand it enables you to serve your father, and away at court it enables you to serve your lord. It instils in you a broad vocabulary for distinguishing birds, animals and plants.
\end{abstract}

(Analects of Confucius 17.9; adapted from the translation by Ames and Rosemont 1998: 206)

\section{Introduction}

In the Analects, Confucius remarks on the inconceivability of a life lacking in xin 信 (2.22). Here, I propose a translation of xin as reliability. In doing so, I locate the meaning of the term in the context of a cultivated life. What are the elements of such a life? Existing discussions in Confucian philosophy highlight its value orientation, focusing on the terms ren 仁 (benevolence), $y i$ 義 (rightness), and $l i$ 禮 (propriety) in ethical terms. Xin is often interpreted, also with ethical overtones, as 'trustworthiness'.

My proposal builds on this work by bringing together the ethical and epistemological aspects of xin. Hence, 'reliability' is not meant to replace all other translations of xin. Rather, I suggest that xin in the Analects has a cluster of meanings (which I explore in the chapter) and that, thinking about it in terms of reliability helps to enrich our understanding of it. By translating xin as 'reliability', I bring out two of its main features. First, I focus on the longer-term consistency in a person's actions and behaviours in different circumstances across time. Second, by saying that reliability is epistemic in nature, we turn our orientation toward knowing how best to act or respond in different circumstances (e.g. to proceed 行; xing; 15.6).

In the first section, I provide an overview of xin and its place in the Analects, including a brief sketch of some influential ways in which the term has been interpreted in scholarship. The second section, 'Acting reliably', situates xin within the context of the demands of official life in the time of Confucius and his early followers by focusing on conversations that relate to lapses in reliability. This helps to explain why reliability is an apt translation for the xin and establishes its place in the Analects. Finally, in the 
last section 'Learning to be reliable', I draw together some elements of cultivation in the Analects, providing a fuller understanding of reliability and how it might be cultivated.

\section{Xin: its place in the Analects}

Xin has a central role in the Analects:

The Master said, 'I am not sure that anyone who [is trustworthy] (xin; 信) is viable as a person. If a large carriage does not have the pin for its yoke, or a small carriage does not have the pin for its crossbar, how can you drive them anywhere?' (2.22; adapted from the translation by Ames and Rosemont 1998: 81) ${ }^{1}$

The character appears in 32 of the Analects' 499 paragraphs. Confucius himself is said to be xin (5.28), and xin was one of his four teachings (the others being the written script, how to handle matters, and loyalty (文, 行, 忠, 信) in 7.25; see also 17.6). Xin has an important role in human relationships: in some conversations, it is coupled with loyalty (忠 zhong; see 1.8, 9.25, 12.10). As the vast majority of human interactions involve verbal exchanges, xin is deeply connected with one's words: in 15.6, a person needs to ensure that his words are sincere and trustworthy (see also 1.13, 5.10).

$X i n$ is particularly prominent in two relational domains. The first is friendship, highlighting the mutual reliance and trust between friends. Close examination of these passages reveals interesting aspects of the conception of friendship in the Analects $(1.4,1.7,1.8,4.28,9.25)$, though it is beyond the scope of this discussion to do that. The second domain is in government, specifically, in the relationship between those in power and the common people. In Analects 12.7, the people's trust (xin) in the government, to ensure the supply of food, and to provide of arms for war, are listed as the top three priorities of government, and ranked in order of importance. The people's trust must be nurtured; it is a responsive relationship that stems from the trustworthiness of those in power $(1.5,13.4)$. Only then will the people come to rely on them (任; 17.6, 20.1; see also 19.10).

Across these passages, we see a number of meanings of xin, clustering around the ideas of trust, trustworthiness, reliance, and reliability. The notion of relationality underlies this cluster of meanings: trustworthiness begets trust; others come to rely on those who are reliable. Therefore, in the literature, there is an influential analysis of xin in terms of the alignment between a person's deeds and his words. This interpretation highlights the graph (信), comprised by two radicals: 个 (or 人), meaning 'human' or 'person', and 言, meaning 'word' or 'what is spoken'. The composite character is often interpreted to mean 'a man standing by his word', noted by Ezra Pound who articulated the views of his teacher Ernest Fenollosa (Pound 1951: 22; see Ames and Rosemont 1998: 53). Pound describes xin in terms of 'fidelity', referring to a person who holds to his promises. ${ }^{2}$ Following Fenollosa and Pound, scholars including especially Dimcheuk Lau - whose translation of the Analects has been influential - have identified the ethical dimension of xin as its major feature, where the focal point is the concordance between a person's words and his actions. ${ }^{3}$ 
Other translators of the Analects offer different perspectives on xin and I mention a few here that will help broaden our understanding of it in current debates. Brooks and Brooks present an interpretation of the Analects shaped by their understanding of the conversations that might have arisen among the early Confucian followers (Brooks and Brooks 1998). For example, they suggest that the coupling of xin with zhong in 15.6 should be interpreted in light of the concerns of official life and its relationships. Here, they argue, loyalty and fidelity are important components of xin. ${ }^{4}$ One effect of the Brooks' interpretive methodology is that it breathes life into some of the terms in the Analects. In this light, xin has an important function in the lives of the early Confucians: '2.22 [the linchpin passage] approaches a definition of what is ethically human, but in active rather than descriptive terms: fidelity is something you do, not something you are' (ibid.: 113).

Ames and Rosemont's translation of xin also focus on its relational aspect and its continuing relevance: $x$ in captures a fiduciary relationship marked by reciprocity. The dual components of such a relation are commitment, on the part of one person, and trust, on the part of the other. For them xin is translated as '[to] make good on [one's] word' (Ames and Rosemont 1998: 81):

every reader of the Analects confronts visually 'person' standing by 'words' or 'speech'. Xin is often translated as 'trustworthy'. However, being simply well intended in what one says and does is not good enough; one must have the resources to follow through and make good on what one proposes to do. Interestingly, as with most classical Chinese terms, in understanding xin we must appreciate the priority of situation over agency. That is, xin in describing the situation of persons making good on their word goes in both directions, meaning both the commitment of the benefactor and the confidence of the beneficiary. Xin, then, is the consummation of fiduciary relationships. (ibid.: 53)

Ames and Rosemont's analysis also foregrounds the moment of interchange captured by $x$ in, where situationality, rather than agency, frames the interaction. Their account is grounded in their view of relational personhood in Chinese philosophy; in subsequent work, they express personhood in terms of roles (Ames 2011; Rosemont and Ames 2016).

Finally, Slingerland's account of xin emphasises agency. ${ }^{5} \mathrm{He}$ draws on the discourse of virtue ethics, suggesting that xin (especially in 13.20) is a 'minor virtue', one that 'can easily be taken too far' (2003: 242); indeed, that it might even become 'a vice through excess' (ibid.: 148). Slingerland also provides some clues concerning how trustworthiness might need to be aligned with rightness ( $y i$ 義) in his commentary on 1.13. Here is Slingerland's translation of 1.13 :

Master You said, 'Trustworthiness comes close to rightness, in that your word can be counted upon. Reverence comes close to ritual propriety, in that it allows you to keep shame and public disgrace at a distance. Simply following these virtues, never letting them out of your sight - one cannot deny that this is worthy of respect.' (ibid.: 5-6) 
In his commentary, Slingerland refers to the views of Huang Kan (黃㑆 1886-1935), who relates the tale of a person who doggedly kept his word to meet with another in heavy storms and drowned; it would have been better if he had not kept his word (2003: 6). Across his various comments on the xin passages in the Analects, Slingerland brings into view the practical import of xin: as much as trustworthiness (conceived as virtue) is important, it must be moderated in practice.

Two prominent features of xin are shared across the analyses we have seen so far. First is its ethical component, expressed in terms of fidelity, that is, the alignment between a person's actions and his words. Ames and Rosemont are right to propose that, at its very core, $x i n$ is a relational concept - for it is a person's fidelity that begets another's trust. This element of xin captures the 'internal' ethical consistency of a person's commitments and actions, which might be a reason why Slingerland expresses it in terms of a person's character (2003: 15). The second feature relates to xin, enacted. Brooks and Brooks emphasise that xin pertains to doing, while Ames and Rosemont stress the dynamic nature of xin, operating at the centre of fiduciary relationships. Importantly, for Ames and Rosemont, xin is expressed in an active phrase, 'making good on one's word' (1998: 53; 74; 81). For Slingerland, the practical element in xin rests primarily in how this 'minor virtue' is brought in line with more weighty considerations in practice.

At this point, we should briefly consider the place and function of xin. What are we expecting, when we seek reliability in a person? In what kinds of tasks is this person reliable? In the context of the Analects, a Confucian scholar-official $(R u$, 儒) would be expected reliably to handle a wide range of matters associated with his position at court. These would have included maintaining his own commitment to humanity (4.4; $4.23)$, proposing institutions that would enable human flourishing $(2.3 ; 12.7)$, advising the ruler, perhaps even to remonstrate with him $(2.19 ; 19.10)$, allocating tasks to the common people (19.10), acting and speaking with tact and decorum (16.6), and, not least, having successful personal relationships $(1.1 ; 1.11 ; 4.18)$. In light of the range of matters the $R u$ would have had to handle, it becomes clear that xin pertains not merely to a person's successes in handling tasks, measured only by their outcomes. This alerts us to the naivete of the question above, that focused on tasks. Rather, xin sits at the nexus of a person's commitments and his actions, realised, consistently, over time. Reliability draws our attention to two dimensions of the commitment-action nexus. First, how do the person's actions bear out his commitments? (Or, how do his actions match his words?) Secondly, is the nexus relevantly and reasonably manifest in action, over time?

These are elements of xin qua reliability that will be explored in the following sections. To summarise the discussion in this section, relationality and situationality are irreducible elements of xin. From a first-person perspective, being trustworthy is not simply about situational consistency between a person's words and actions. It is also about a person's moral identity over time, manifest in both his words (commitment) and deeds: making promises he has kept, or withdrawing from agreements when weightier moral factors bear on the situation at hand, or reviewing his undertakings, and so on. The longitudinal aspect of xin, manifest in a person's actions through time, is best captured by the term 'reliability'. When we reflect on the two relationships in which xin figures most prominently - friendship and trust in government - it is not 
simply that we trust (or should be able to trust) friends and those in power in the relevant moral senses, but also that we can reliably count on them in pertinent ways. In the next section, I provide more support for the notion of reliability in the Analects by investigating some conversations relating to action.

\section{Acting reliably}

The conversations we examine in this section do not necessarily mention xin. However, they present scenarios where correct or appropriate actions are taken, or not. The key passage here is 5.22 , where Confucius expresses frustration at his young followers' failure to act aptly in particular situations. The discussion here picks out particular passages in the Analects that highlight the importance of taking appropriate action. I suggest that a person's ability to act appropriately in different situations, over time, is his reliability, manifest in practice. I begin this discussion by drawing attention to the connection between xin and practical action before moving on to examine Confucius' frustration in 5.22 .

Analects 15.6 identifies xin as one of four rudiments in the life of an effective official:

Zizhang asked about getting by in the world (xing 行).

The Master replied, 'In your speech, be dutiful and trustworthy, and in your conduct be sincere and respectful. In this way, you will always get by in the world, even if you find yourself in some barbarian state. If your words are not dutiful and trustworthy, and your conduct is not sincere and respectful, how can you possibly get along, even in your own region? When standing still, visualize these principles standing by your side; when riding in your carriage, see them resting before you on the crossbar. Only then will you get by in the world.'

Zizhang then wrote these words on the end of his sash. (trans. Slingerland 2003: 176)

In the broadest sense, the term xing refers to movement or process. In this passage, Zizhang comes to Confucius with a question about how he is to proceed in carrying out official duties. Slingerland fittingly interprets Zizhang's question as a concern about 'getting by in the world', hence reflecting Zizhang's preoccupations with official life. Though not explicit, this conversation reveals the importance of preparation for official life: the advice is for Zizhang to be mindful of the principles he has learnt; accordingly, he writes these words on his sash to remind himself of them.

The problem is not simply one of recalling what one has learnt, however. In 5.22 , Confucius is annoyed at his young followers, who are unable to do what is situationally appropriate:

The Master was in the state of Chen, and said, 'Homeward! Homeward! My young friends at home are rash and ambitious, while perhaps careless in the details. With the lofty elegance of the literatus, they put on a full display of culture, but they don't know how to cut and tailor it.' (trans. Ames and Rosemont 1998: 101) 
These young men seem to have absorbed prevailing customs and appropriate decorum but are unable to adapt them to the situation. This passage expresses one of the perils of learning: in one sense, a person can be a good learner as they demonstrate full competence in performing what they have been taught; in another sense, the unreflective, context-insensitive application of learnt behaviours is hardly a sign of successful learning. The Mencius, another early Confucian text, makes a connection between this passage and several others that focus on the 'village worthy' (xiang yuan 鄉原) (Mencius 7B.37; which refers to the conversations in Analects 13.21 and 17.13). What is so problematic about such a person?

'If you want to condemn the village worthy', said Mencius, 'you have nothing on him; if you want to criticize him, there is nothing to criticize. He chimes in with the practices of the day and blends in with the common world. Where he lives he seems to be conscientious and to live up to his word, and in what he does, he seems to have integrity.' (Mencius 7B.37; cited in Ames and Rosemont 1998: note 86 , p. 239$)^{6}$

In the Analects, the passage on the village worthy (17.13) is immediately followed by a negative comment on those who unthinkingly repeat what they hear:

The Master said, 'To hear something on the road, and then repeat it everywhere you go, is to throw Virtue away.' (17.14; trans. Slingerland 2003: 206)

Slingerland notes that number of commentators draw the lesson that blind repetition falls significantly short of understanding and realisation (expressed in the term zhi (知 or 智), often translated 'knowledge' or 'wisdom'). Analects 17.14 is explained in light of Analects 2.11, which gives central place to the apposite application of one's learning to the situation at hand. In 2.11, Confucius is meant to have remarked, 'Revising the old in order to realise the new; this is a teacher indeed' (trans. Lai).

Slingerland explains his translation of 17.14 with reference to 2.11, drawing on Huang Kan's (皇㑆; 488-545) commentary: as Huang Kan explains, 'Mere rote-learning is not sufficient to make one a teacher of others. In order to teach others, one must first be able to "both keep past teachings alive and understand the present" [2.11], and one must examine what one has learned in detail and practice it for a long time. Only then is one ready to repeat and transmit teachings to others. If, instead, one hears something on the road, and then turns around and repeats it to someone else, a great deal of nonsense and foolishness will inevitably be the result' (ibid. 206). Huang Kan and earlier commentators $^{7}$ point out that each situation is unique - new - in that it has distinctive circumstantial features that bear on the decision to be made.

Let us return to 5.22, where Confucius uses the metaphor from tailoring (cai 裁), to express his followers' lack of ability to adapt their learning to the situation at hand. What does tailoring involve? Each piece of tailored clothing is made to fit a particular person. Specific considerations are brought to bear, including the physical measurements of the wearer, the style of clothing and the print, colour and weave of the cloth. Interestingly, the English phrase 'to tailor' has similar connotations of taking 
action that is fitting under particular circumstances. ${ }^{8}$ Indeed, the term 'tailor' can be, and is, used metaphorically exactly to make the point about fit. We might hear, for instance, the following comment in a business context: 'We'll need to tailor the proposal to the situation at hand.' Likewise, Confucius was using the term metaphorically.

Each tailored piece is, in effect, a 'new' piece. It is, to use a phrase in today's consumer context, 'custom made'. Each tailored piece, cut and sewn well, testifies to the tailor's reliability, and her expertise. Here, we take it that 'reliability' in the relevant sense implies that the tailor is not merely competent but, in fact, does an impressive job, time and time again; for we would not call the tailor 'reliable' if her work left much to be desired., ${ }^{9,10}$

If reliability is a concern in the Analects, as I have suggested here, does the text have any advice to offer in relation to its cultivation? How does a person learn to be reliable in what he or she undertakes? How might learning processes incorporate both familiarisation with prevailing norms and practices, and development of insight and initiative to adapt one's knowledge to the situation at hand? I believe that the Analects provides some clues on how reliability may be cultivated. In the final section, I construct a picture of cultivation from selected conversations in the Analects.

\section{Learning to be reliable}

In this section, I outline a number of processes associated with cultivation: familiarisation, reflection, and practice. I use these terms not to pick out clearly defined, independent stages of learning, nor do I suggest that they correspond to specific terms in the Analects. However, these categories are conceptually helpful in setting out the terrain in the Analects, highlighting its various components of cultivation. I discuss each in turn.

\section{Familiarisation}

Not a few conversations in the Analects stress the importance of picking up cues from the surrounding environment. For example, Confucius is described as a keen observer (guan 觀; to observe) of human behaviour (e.g. 2.10), and he recommends that we learn from others who are exemplary, but also from those whose behaviours leave much to be desired (7.22). ${ }^{11}$ Confucius' advice is to learn from a wide range of sources - to learn broadly (boxue 博學) - as he himself does $(6.27 ; 9.2 ; 12.15 ; 19.6)$. Moreover, a person should learn not only from social interactions but from reading books ( $d u s h u$ 讀書; 11.25) such as the Book of Odes (Shijing 詩經) and the Book of Documents (Shujing 書經) $(1.15 ; 3.8 ; 7.18 ; 8.8 ; 13.5 ; 16.13)$. The Odes is also a resource for learning about the natural world (17.9).

The Analects also proposes a variety of methods for familiarising oneself with the world and with its prevailing norms and practices. These include listening (wen 聞; e.g. $1.10 ; 2.18 ; 4.8 ; 5.9 ; 7.3 ; 7.28$, etc.), asking questions (wen 問; $3.15 ; 5.15 ; 10.14$; $16.10 ; 19.6)$, having discussions - indeed, many of the conversations feature Confucius having conversations with his followers (yan 言; e.g. $1.15 ; 3.8 ; 7.18$ ), and practising ritual propriety ( $l i$ 禮; $6.27 ; 12.15$ ). Finally, we should not forget to mention the process 
of familiarisation with names (zhengming 正名), a process by which a person learns correct names (such as father, wife, and official) and applies them to conduct. In 13.3, zhengming is a priority of government: the correct use of names underlies all aspects of sociopolitical life as it is a system of standardisation. ${ }^{12}$

This quick survey of the sources and methods of familiarisation provides a deeper understanding of a set of related themes on learning in the Analects, including why it is important to have like-minded friends (1.8), how following ritual propriety may help anchor a person in the received norms and practices of the time, the place of tradition, as well as the need for the early followers to orientate their lives in the tumultuous times of the Warring States (Zhanguo 戰國; 475-221 BCE). This overview also reminds us of the seeming fixation on the past in some of the conversations, including those in which Confucius seems to be yearning for the Zhou and its customs $(3.14 ; 7.5 ; 17.5)$, at one point claiming not to be a creator (of new ways) as he was only a transmitter (of tradition) (7.1). Yet, other passages challenge this picture, portraying Confucius as an adept interpreter of the past, authoritatively modifying customary practices (e.g. 9.3). What could the Confucians have learnt from the past? And what can we learn from the Analects? Above all, how can learning from the past help us become more reliable?

Recall the discussion in the previous section that centres on acting in the moment; we also saw how quite a few of the conversations expressed concern about the failure to adapt one's learning to the situation at hand. In light of this, it seems reasonable to suggest that, in the Analects, learning consists in familiarising oneself with what has gone before, so as to build a repository of information on what has worked in the past and what not, as well as the range of possibilities for action. This store of information will help to inform the decision being made in the present: the new. Discretion is emphasised in 7.28, where Confucius explicitly states how information from the past is adapted:

There are some who, without knowledge, forge new ways, but I do not do that. I listen widey, select what works well, and follow it. I look widely and remember what I see. This is a second tier of knowledge. (trans. Lai)

In 16.9, Confucius claims that those who are born with knowledge (sheng er zhi zhi zhe 生而知之者) are of the highest tier, while the second - to which he belongs - consists of those who study in order to acquire knowledge (xue er zhi zhi zhe 學而知之者). In 7.20, Confucius notes that he himself was not born possessing knowledge but that he earnestly seeks it. Together, these three conversations suggest the centrality of acquiring knowledge (even though some might be born with particular insights). Analects 7.28 also cautions against undertaking matters without knowledge. ${ }^{13}$ In the Analects, the term to study or learn ( $x$ ue 學) has a range of meanings associated with a person's familiarisation with prevailing norms and practices. This kind of learning is necessary, but not sufficient, for cultivation.

\section{Reflection}

So far, we have seen that the learner builds up a repository of knowledge through the processes of familiarisation. To be able to reproduce actions or behaviours is hardly 
adequate; discretion is needed to $u s e$ and adapt the information to the present situation. In 2.15, xue is contrasted to, but also coupled with, reflection ( $s i$ 思): Confucius said, 'Learning without due reflection leads to perplexity; reflection without learning leads to perilous circumstances' (trans. Ames and Rosemont 1998: 79). Reflection must be brought to bear on what a person has learnt. For a person simply to have a large and unwieldy volume of information is hardly desirable. Analects 15:31 suggests that learning is a less demanding processes than reflection:

The Master said, 'Once, lost in my thoughts [si], I went a whole day without eating and a whole night without sleeping. I got nothing out of it, and would have been better off devoting the time to learning [xue].' (trans. Ames and Rosemont 1998: 190)

From these two conversations, it seems that reflection is an activity that involves stepping back from existing beliefs and practices to properly assess them. Perhaps that is why it is reckless to engage in reflection without full understanding. ${ }^{14}$ As we might expect, there are not many clues concerning the cognitive and psychological aspects of reflection. However, I discuss three examples below which exemplify the hallmarks of reflective reasoning that constitute an exemplary life and the adaptation of old to new, even though they do not explicitly make the connection between $s i$ and its outcomes in reasoning.

In the first conversation, in Analects 9.3, Confucius diverges from traditional prescriptions to follow current practices on one issue: he wears a silk cap rather than a linen one as the former is more economical. On another issue, however, he rejects the then popular practice for a more traditional approach: he bows before ascending the steps to a hall with an altar. Two aspects of this conversation are interesting. First, Confucius stands independently from both inherited tradition and prevailing standards. In each case, he provides reasons why he chooses to maintain tradition or follow contemporary practice. Secondly, it is intriguing that the author of this passage deemed it important to compose this anecdote, which speaks to Confucius' independence from norms as well as his ability to reason on a case-by-case basis, adapting what he knew to the case at hand.

In my second selected scenario, Confucius expresses dissatisfaction relating to the term ' $g u$ ' (触), a ritual vessel:

A $g u$ ritual drinking vessel that is not a $g u$ ritual drinking vessel - a $g u$ indeed! A gu indeed! (6.25; trans. Ames and Rosemont 1998: 109)

What was Confucius criticising? Brooks and Brooks suggest that this utterance subtly refers to ren, no longer carrying any significant moral weight in Confucius' time (1998: 36). Another interpretation of this comment draws on the debate on zhengming. On this view, Confucius was posing a challenge to the incorrectness of the name that was used. The term ' $g u$ ' had originally referred to a cornered drinking vessel but the vessel had changed even though its name was still in use. Legge, an early translator of the Analects, suggests this and states that 'The name without the reality is folly' (1991: note 23, p. 75). ${ }^{15,16}$

Whatever the original intentions of the utterance, we see here another instance of Confucius standing at the crossroads of tradition and current practice. Confucius 
reflects on the use of ' $g u$ ' as a label, commenting on its lack of fit with his observations of the world. In contrast to a learner, who is just grasping the scope of names and applying them unreflectively, Confucius (unhappily) notes the shifts in its meaning, standing back and criticising its incorrect use.

In a third example, Confucius gives different answers to two followers who ask the same question. An observer, Gongxi Hua, asks why he has given opposing prescriptions to different people:

Zilu inquired, 'On learning something, should one act upon it?' The Master said, 'While your father and elder brothers are still alive, how could you, on learning something act upon it?' Then Ranyou asked the same question. The Master replied, 'On learning something, act upon it.'

Gongxi Hua said, 'When Zilu asked the question, you observed that his father and elder brothers are still alive, but when Ranyou asked the same question, you told him to act on what he learns. I am confused - could you explain this to me?'

The Master replied, 'Ranyou is diffident, and so I urged him on. But Zilu has the energy of two, and so I sought to rein him in.' (11.22; trans. Ames and Rosemont 1998: 146-7)

A few observations may be made of this conversation. First, it demonstrates the need for tailoring responses to different people; it could be taken as an example of how Confucius knew people (zhiren 知人), an important skill for a ruler or higher official to have, in order to allocate fitting responsibilities to officials with particular capabilities $(1.16 ; 12.22 ; 20.3)$. Secondly, the focus here is not on the prescriptive remarks Confucius makes to Zilu and Ranyou. Rather, it is on why Confucius gives the different responses. Thirdly, and perhaps most interestingly, Confucius is portrayed as a person attuned to the needs of different people - perhaps as a teacher par excellence, who responds reliably in a wide range of scenarios.

\section{Practice}

What can a person do to develop capacities like those exemplified in these three (and other) conversations in the Analects? We have so far seen the importance of acting in the moment that requires a person to apply their learning to the situation at hand. ${ }^{17}$ In the Analects, the attentiveness to practicalities looms large; all of Book Ten expresses Confucius' focus on the details of the circumstances - as, for instance, he would not sit on his mat unless it was straight (10.9). And, indeed, if a reader expects only to extract conceptual lessons from the Analects, Confucius will come across as overly fussy and pedantic. It is not only in Book Ten, but across its chapters, that the conversations are situationally focused.

A person develops awareness of situationally relevant details through practice, by handling tasks in a range of situations, finding out what works and what does not. Through practice, a person puts to test her assumptions, estimates, and imagined possibilities. Recall the term xing (行) which, in its broadest sense, refers to movement or action. Xing may also refer to what is permissible (1.12), what the norms prescribe 
(15.11; 15.24; 16.11; 17.6), appropriate conduct $(2.18 ; 5.10)$, the possibility of putting something into practice $(2.13 ; 5.20 ; 15.18)$, whether something can be attained or an action realised $(11.3 ; 13.3 ; 14.36 ; 18.7)$, and the conditions that limit what may be achieved (5.7; 5.14). In the Analects, xing may best be described as the possibility of alternative actions in any one situation, in light of relevant constraints and enablers. ${ }^{18}$

It is only through taking action that a person can cultivate sensibilities ${ }^{19}$ for the range of possibilities associated with particular types of actions. In each action, a person's repository of knowledge is articulated. Working out possibilities and reflecting on them in light of one's commitments is, I suggest, at the heart of cultivation. In time, and with due diligence to learning and reflection, a person builds a repertoire of successful and effective actions. ${ }^{20}$ Accordingly, when a person builds her repertoire, she will also enhance her reliability. She not only has access to a repository of knowledge - which is also available for all those who apply themselves to learning - she has developed her own repertoire. For those who know her, their understanding of what she is capable of and what she is likely to achieve is formed through time and, if convinced, they will rely on her in relevant ways.

What might a reliable person be like? In the Analects, we see some glimmers of Confucius of whom, we may say, is reliable: he knows when he should no longer trust what people say (5.10), he knows to provide different answers to different people (11.22), and he knows, for example, not to force a person without moral compunction to comply with existing behavioural ritual norms (17.21). Together, these anecdotes and others help us build a picture of Confucius' reliability. Indeed, it is quite plausible that it was the intention of the authors of some of the passages and the compilers of the text, among other things, to convey this picture of Confucius as a person who, among other notable characteristics, may be described as xin. The text presents a picture of Confucius as a person who is reliable in action, in his behaviour and the advice he gives.

In conclusion, I summarise my key arguments and consider their implications for Confucian agency and cultivation. Xin qua reliability has important moral, temporal and relational aspects. From a relational point of view, we come to believe a person is reliable - and may come to rely on them for particular things - only after she has, through time, acted reliably. From an agent's point of view, each situation is 'new' in the sense that it will present different salient factors which will bear on his intended actions and their outcomes. Neither agency nor situationality takes precedence in this account. The agent applies his capabilities and skills in response to the opportunities and constraints that arise with each situation. This view of agency has a dynamic dimension, lending itself to a narrative account of personhood. Each action is significant as, together with others and taken over time, it cumulatively adds to a picture of agency. Isolated lapses or failures may not necessarily alter the perception of a person's ability, just as a celebrated musician's slip up at one concert may not necessarily affect her reputation as a skilled performer. Nevertheless, if a pattern of mishaps develops over time, our picture of her reliability will change.

In this chapter, I have placed xin at the centre of Confucian life - following 2.22 that sees it as the linchpin of personhood. The interpretation offered here draws our attention to action - and cultivation - that sits at the crossroads of ethics and epistemology. Acquaintance with a repository of information about moral norms and practices is 
inert until it is enacted, expressing the agent's moral commitment and epistemological capabilities, together with her skills, qualities, and dispositions. The focus on reliability highlights the nature of Confucian agency whereby taking situationally appropriate action is constitutive of a person's repertoire of successes (measured in task-relevant ways) in particular areas; and, conversely, where practice and experience helps attune a person to morally weighty considerations that arise in different contexts. This account of xin yields a rich and dynamic picture of cultivation, agency, and relational selfhood in Confucian philosophy.

\section{Notes}

1 In opening this discussion, and for the sake of simplicity, I use 'trustworthiness' as a translation for xin; I will introduce the subtleties of the term in the course of the chapter. In modifying Ames and Rosemont Jr's translation, I have replaced 'does not make good on their word' with 'is trustworthy'.

2 Pound says this about the character: 'Fidelity to the given word. The man here standing by his word' (1951: 22).

3 D. C. Lau writes: 'To be $[x i n]$ is to be reliable in word. An important part of this has, of course, to do with promise-keeping. But when Confucius talks of being $[\mathrm{xin}]$ in word (I.7; XIII.20; XV.6), he means more than that. To be $[x i n]$ in word applies to all one's words. It concerns, besides promises, resolutions concerning future conduct, or even plain statements of fact. Not to carry out a resolution is to fail to be [xin]; to have made a statement not borne out by facts - whether they be present or future facts - is equally to fail to be xin.... Confucius often opposes the terms [yan] (word) and [xing] (deed). For one's deed to fail to match one's word is to fail to be [xin]' (1979: 25). Lau explains $x i n$ and a handful of other terms in the Analects in terms of 'the moral qualities of the gentleman' (1979: 31).

4 Refer to the commentary on this conversation (Brooks and Brooks 1998: 132). See also their commentaries on 2.21 and 2.22, whereby zhong in 2.21 concerns 'vertical loyalty' while xin in 2.22 pertains to the "lateral "fidelity" (1998: 113). This is not the only way Brooks and Brooks understand xin. Their analysis of the term differs across the different conversations in the Analects, depending on which conversations are attributed to which speakers or groups.

5 Slingerland notes that, in the linchpin passage, xin may refer to trustworthiness as a facet of an individual's character or of the nature of social relations (2003: 15). This stands in clear contrast to the Brooks' view that xin pertains more to action (what one does) rather than character or virtue (who one is).

6 Refer also to Slingerland's commentary on 17.13, where he notes of the village worthy, that 'by serving as counterfeit models of virtue for the common people, the village worthy is in effect a false prophet, not only blocking the development of true virtue in himself but also leading others astray' (2003: 206).

7 In fact, Huang Kan's commentary draws from the ideas of He Yan (何晏; c. 195-249). He Yan's commentary states, 'Teachers must revise the old to realise the new, engage in close study and extended revision (practice). Then only can they successfully transmit their words. If you (simply) hear things along the way, and transmit that, you will be spreading falsehoods' (trans. Lai). 《欽定四庫全書》本。本書10卷，拆分成5冊。 
影印古籍 欽定四庫全書·經部八·四書類 論語集解義疏; 論語集解義疏卷九 卷十 (pp. 26-27/112).

8 There is another interesting metaphor in the Analects, quan (權), meaning to 'weigh' and used in the Analects to refer to 'weighing up', sometimes in exigent circumstances $(9.3 ; 18.8)$. Refer to Antonio Cua's helpful discussion of quan and jing in relation to Mencius' philosophy (2005: 351, note 14).

9 We might jokingly say that the tailor with poor skills was 'reliably inaccurate in measuring hem lengths', but the joke in fact rides on overturning the meaning of the term 'reliable'.

10 Back to the young followers of Confucius: we would expect a variety of reasons for their failure to tailor their actions to particular situations as needed. In 9.29, Confucius recognizes that confusion at the point of action is a significant problem: 'The Master said, "The wise ( $z h i$ 知) are not in a quandary [huo 惑]; the authoritative (ren 仁) are not anxious; the courageous are not timid."' (9:29; trans. Ames and Rosemont 1998: 132). The term for confusion, 惑, is comprised by two characters, 或 (huo), meaning (to have) alternatives, and 心 (xin), which means the human mind-heart. The composite character signifies a mind-heart which does not know which alternative to pick. One example of confusion is provided in 12.21, where a person in a fit of rage loses sight of his priorities (forgetting himself and even his parents). In 12.10, a contrast is set up between rectitude and being in a quandary: 'Zizhang enquired about accumulating rectitude and distinguishing (and clarifying) confusion. Confucius replied, "Prioritise loyalty and reliability (xin), and follow the right; this is to accumulate rectitude. To simultaneously love and hate someone, and thus to simultaneously want this person to live and to die, is to be in a quandary..." (trans. Lai; adapted from the trans. Ames and Rosemont 1998: 156).

11 It is noteworthy that guan, observation, also has a fundamental place in the Yijing's (Book of Changes 易經) Appendices; it is how one begins to understand the world and it enables a person to orientate himself in the world: 'When in ancient times Lord Bao Xi ruled the world as sovereign, he looked upward and observed [guan] the images in heaven and looked onward and observed [guan] the models that the earth provided. He observed the patterns on birds and beasts and what things were suitable for the land. Nearby, adopting them from his own person, and afar, adopting them from other things, he thereupon made the eight trigrams in order to become thoroughly conversant with the virtues inherent in the numinous and the bright and to classify the myriad things in terms of their true, innate natures' (Xici zhuan 2.2; trans. Lynn 1994:77; annotations by Lai).

12 Holloway links the idea of zhengming with 17.9, proposing that 17.9 - the conversation on reading the Odes quoted above - may help fill out the broadest understanding of zhengming, as a way of 'clarifying and ordering our world' (2013: 95).

13 There are different interpretations of this passage. Ames and Rosemont Jr. link this comment with 7.1, where Confucius claims that he is a transmitter and not an innovator. Their translation focuses on those with who create without knowledge (the first tier of knowledge), with Confucius claiming only the second for himself. Their translation of the first sentence reads: 'There are probably those who can initiate new paths while still not understanding them, but I am not one of them' (1998: 117).There is another possible translation of this statement that is somewhat more ambivalent about those who create without knowledge (the view taken here in my translation). According to this view, Confucius distances himself from this first type of person. However, his own approach belongs to a second tier; the first tier is the person who is 
born with knowledge, referred to in 16.9 and 7.20, and not those who act or initiate without knowledge.

14 Other examples where Confucius' interlocutors seem to speak or act precipitously include 11.22 and 13.3.

15 Legge argues that the term $g u$ referred to a cornered vessel, captured in jiao (角), one of the components of $g u$. According to Legge, jiao referred to a 'horn' - a sharp corner and in Confucius' time, the form of this ritual vessel was changed while its name was kept. Legge believes that this statement hinted at the inept government of the day (1991: note 23, p. 75).

16 Refer to the helpful discussion of the relation between zhengming and ethics, and whether this passage fits within the ambit of zhengming, in Loy (2014).

17 In earlier work, I suggest that the primary epistemological notion in the Analects is best described as 'knowing to act in the moment' (Lai 2012).

18 Another term in the Analects captures the sense of practice, with emphasis on performance $(x i$ 習: $1.1 ; 1.4 ; 17.2)$. In 1.1 , Confucius says that it is a joy to be able to learn through practice, at appropriate moments (學而時習之). A few translators interpret this phrase as a conjoint of two elements, the second taking place only after the first, with the intention to capture the stages of learning: first to learn, then to practice (e.g. 'To learn something and then to put it into practice at the right time' (trans. Leys 1997: 3), and 'Having studied, to then repeatedly apply what you have learned' (trans. Ames and Rosemont 1998: 71)).I suggest a different reading, however, connecting learning and practice: 'Learning, just like practising in a timely way'. I have translated 'er' (而) to mean 'alike' ( $r$ u 如) (Pulleyblank 1995: 148; Schuessler 2007: 224), which understands timely practice as a way to learn. My translation also interprets shi (時) as timeliness rather than frequency (shishi 時時); compare Leys' and Ames and Rosemont's translations above.

19 The Analects does not provide sufficient detail to allow us to construct an account of what this entails. However, scholars have drawn on other contemporaneous texts including the Mengzi and the Xunzi to offer a more substantial picture of moral cultivation. See, for example, Shun (1997); Chan (2002); Chong (2007); Yu and Ivanhoe (2010); and Kline and Tiwald (2014).

20 I have not mentioned a person's moral commitment to others in her undertaking to be trustworthy and reliable. Suffice to say here that the discussion here takes it as implicit that xin incorporates this moral undertaking. This chapter does not intend to exclude xin's moral dimension but rather seeks to flesh out ways of cultivating xin.

\section{References}

Ames, R. (2011). Confucian Role Ethics: A Vocabulary. Hong Kong: Chinese University Press.

Ames, R. and H. Rosemont Jr. (1998). The Analects of Confucius: A Philosophical Translation. New York, NY: Ballantine Publishing Group.

Brooks, E. B. and A. T. Brooks (1998). The Original Analects: Sayings of Confucius and His Successors. New York: Columbia University Press.

Chan, A., ed. (2002), Mencius: Contexts and Interpretations. Honolulu: University of Hawai'i Press. 
Chong, K.-C. (2007). Early Confucian Ethics: Concepts and Arguments. Chicago, IL: Open Court Publishing.

Cua, A. (2005). 'Xin (Mind/Heart) and Moral Failure: Notes on an Aspect of Mencius' Moral Psychology', in A. Cua (ed.), Human Nature, Ritual, and History: Studies in Xunzi and Chinese Philosophy, 348-70 (Studies in Philosophy and the History of Philosophy). Washington, DC: Catholic University of America Press (first published in 1999).

Holloway, K. (2013). The Quest for Ecstatic Morality in Early China. New York: Oxford University Press.

Kline, T. C. (III) and J. Tiwald, eds (2014). Ritual and Religion in the Xunzi, SUNY series in Chinese Philosophy and Culture. Albany, NY: State University of New York Press.

Lai, K. (2012). 'Knowing to Act in the Moment: Examples from Confucius' Analects', Asian Philosophy, 22 (4): 347-64.

Lau, D. C., trans. (1979). Confucius: The Analects (Lun yu). Translated with an introduction by D. C. Lau. Harmondsworth, UK: Penguin Books.

Legge, J., trans. (1991). Chinese Classics: With a Translation, Critical and Exegetical Notes, Prolegomena, and Copious Indexes. Taipei: SMC Publishing Inc.; reprinted from the last edition by Oxford University Press; vol. 1: Confucian Analects, The Great Learning, The Doctrine of the Mean (3rd edn), with a Biographical Note by L. T. Ride.

Leys, S., (a.k.a. Pierre Ryckmans) trans. (1997). The Analects of Confucius: translation and notes by Simon Leys. New York: W. W. Norton.

Loy, H.-C. (2014). 'Language and Ethics in the Analects', in A. Olberding (ed.), Dao Companion to the Analects, 137-58. Netherlands: Springer Publishing.

Lynn, R. J., trans. (1994). The Classic of Changes: A New Translation of the I Ching as Interpreted by Wang Bi. New York: Columbia University Press.

Pound, E., trans. (1951). Confucius: The Great Digest, The Unwobbling Pivot, The Analects. New York: New Directions.

Pulleyblank, E. G. (1995). Outline of Classical Chinese Grammar. Vancouver: University of British Columbia Press.

Rosemont, H. Jr. and R. Ames (2016), Confucian Role Ethics: A Moral Vision for the 21st Century?, Göttingen; Taipei: V\&R Unipress; National Taiwan University Press.

Schuessler, A. (2007). ABC Etymological Dictionary of Old Chinese. Honolulu: University of Hawaii Press.

Shun, K.-L. (1997). Mencius and Early Chinese Thought. Stanford: Stanford University Press.

Slingerland, E., trans. (2003). Confucius Analects: With Selections from Traditional Commentaries. Indianapolis: Hackett Publishing.

Yu, K.-P., J. Tao and P. J. Ivanhoe, eds (2010). Taking Confucian Ethics Seriously: Contemporary Theories and Applications. Albany, NY: State University of New York Press. 